\title{
Negotiating Alternative Masculinities in Men's Magazines: Transitivity in the Formation of Counter Hegemonic Identities
}

\author{
Nur Syuhada Mohd Radzi ${ }^{a}$ \\ p77775@siswa.ukm.edu.my \\ Faculty of Social Sciences and Humanities, \\ Universiti Kebangsaan Malaysia, Malaysia \\ Kesumawati A. Bakar ${ }^{b}$ \\ kesuma@ukm.edu.my \\ Faculty of Social Sciences and Humanities, \\ Universiti Kebangsaan Malaysia, Malaysia \\ Bahiyah Dato' Hj. Abdul Hamid \\ bahiyah@ukm.edu.my \\ Faculty of Social Sciences and Humanities, \\ Universiti Kebangsaan Malaysia, Malaysia
}

\begin{abstract}
With social transformation and male empowerment, the archetypes of traditional masculinity are being deconstructed and rendered obsolete. The changing view of masculinity demands for an exploration of how popular media, particularly men's magazines rewrite the discourse of masculinity. Attempting to answer the overarching question of 'what does masculinity mean today?', this paper explores identity as a linguistic phenomenon. Drawing on both Critical Discourse Analysis (CDA) and Halliday's Transitivity system of the Systemic Functional Linguistic (SFL) frameworks, we examine ideational meanings realised by lexicogrammatical selections and discourse-semantic-choice involving process types and participants' role that form counter hegemonic masculinities. This study argues that as men negotiate their identities, magazines play a critical role in challenging patriarchal masculinity and normalising alternative masculine practices via ideologies embedded in a text. The investigation focuses on how transitivity is drawn on to produce counter hegemonic formations and how different enactments of masculinities are articulated in magazine texts to present alternative forms of male identities. Drawing from 584,600-word corpus of selected men's magazines titles published from 2016 to 2020, findings revealed the use of material, mental, relational and behavioural processes that manifests counter hegemonic identities or non-traditional representation. Evidence from the corpus reflects various projections of men as emotionally vulnerable, aesthetically conscious, domestically competent and antihomophobic. The implication highlights the different ways media language creates and facilitates the changes in masculine practices and how magazine texts infuse or indoctrinate alternative identities as a stable performance of masculinity.
\end{abstract}

Keywords: masculinity; systemic functional linguistics; critical discourse analysis; corpusbased study; media discourse

\section{INTRODUCTION}

The recent years have seen emerging scholarly works devoted to realign and redefine meanings of masculinity. Over the past several years, masculinity has become the universal explanation for the rising anxiety and psychological dilemmas in many men (Harper, 1998; Ramaeker \&

${ }^{a}$ Main author

${ }^{b}$ Corresponding author 
Petrie, 2019). This observation rests on an acknowledgement that stereotypes, norms and social patriarchy still exist and remain forceful, despite not explicitly endorsed in today's society (Kluch, 2015). Our culture prescribed specific characteristics of masculine constructs to fit the patriarchal social system and traditional masculinity standards marked by stoicism, dominance, aggression and competitiveness (Horrocks, 1994; Kaufman, 1994; Kimmel, 2018). Starting at a young age, men and boys learn from their experience that appropriate enactments of masculinity involved a display of toughness, risk taking behaviours, emotional restraint, disdain for homosexuality, self-sufficient attitudes and domination against women (Espelage et al., 2018). These traditional masculine practices are what Connell (1987) termed as the hegemonic masculinity - a dominant socially constructed concept that perpetuates inequalities between groups, which privileges the position of some men over other (often minority group of men) and the subjugation of women and groups perceived to be feminine (i.e. homosexuals) (Connell \& Messerschmidt, 2005).

The endorsement of hegemonic masculinity and the need to adhere to certain unrealistic and unattainable masculine norms appear to confer risk for depressions and induce anxieties in men (Donaldson, 1993; Kaya et al., 2019). Our social expectations of men and boys are for them to be strong, aggressive and emotionally restraint, thus, deviation from these masculine constructs can result in backlash and ostracism. For instance, male leaders who ask for help or display vulnerability are viewed as less competent and capable (Rosette et al., 2015), while men who are more communal and agreeable (i.e. warm, supportive, caring and sympathetic) earn lesser than more stereotypically masculine men (Judge et al., 2012). Similarly, men who display sympathy and express sadness by crying at work (refer Brescoll \& Uhlmann, 2008) are more in danger of career derailment as opposed to sympathetic or sad women, naturally because men are thought of less deserving of those emotions. These descriptions highlight Kaufman's (1994) view of 'men's contradictory experience to power' (pg.143) in which he believes that the rigidity of masculine practices has not only penalised men for failing to conform but also caused "immense pain, isolation, and alienation" (Kaufman, 1994, p.59) for them. This perspective is echoed by Horrocks (1994), who emphasises that the negotiation of hegemonic masculinity has become a struggle for many men because it "requires such a self-destructive identity, a deeply masochistic self-denial, a shrinkage of the self, a turning away from whole area of life, that the man who obeys the demands of masculinity has become only half human" (p.25).

A growing body of scholarship has documented the multifaceted and complex ways that modern society construes understanding of masculinity and separately how hegemonic masculine adherence places men at risk for toxic masculinity (Kaufman, 1994; Kimmel, 2018). Yet, little attention has been paid to address how counter hegemonic masculinity is conceptualised in media avenue as men's magazines, which as Benwell (2003) explicates, rose in popularity as a result of male crisis and men's desire to relocate their identity in post-feminist world. As scholars emphasised, a critical task for individual level work concerning masculinity is to initiate a process of intervention, to reflect on the implications of ways of practicing and awareness of alternatives to work towards equality and human liberation (Carabi \& Armengol, 2014). Moreover, examining the social construction of masculinity denaturalise both its superiority and its form, calling men's superordinate social status into question, dismantling 'men's false entitlements to unequal power' (Carabi \& Armengol, 2014, p.9), rejecting the naturalness of hierarchical social structure, and projecting that change is possible. Scholars like Kimmel (2018) and Brod (2018) believe that in an attempt to rectify the crisis in masculinity, studies should try to contest normative masculine behaviours related to conventional ideals and promote more holistic, progressive ways of practicing masculinity. A better understanding of alternative masculinity is crucial to reduce segregations and discriminations between groups and increase support for gender justice, but no research- informed enumeration exists to 
reconfigure how the new legitimate forms of masculinity are represented in popular media discourse. Considering this and the saturated magazines representations as well as the excessive media consumption, it seems inevitable to ignore the pedagogic influence men's magazines have in teaching men and boys about masculinity. CDA as a broad approach in this study is "fundamentally interested in analysing opaque as well as transparent structural relationships of dominance, discrimination, power and control as manifested in language" (Wodak, 2001, p.2). Likewise, Fowler (1991, p.101) notes that "anything that is said of written about the world is articulated from a particular ideological position", which then construct the social manifestations of the beliefs that mirrors social relationships and therefore articulate and internalise new gender ideas in the society. Assuming that the discourse in magazines is inextricably powerful in shaping one's identities and establishing social reality, on top of the detrimental impact that rigid masculinity ideologies place on men, - it becomes important to disrupt and destabilise the hegemonic construct. This article attempts to deconstruct notions that support the male supremacist status quo by questioning the validity of hegemonic structures and paves the way for alternative forms of masculinity. It looks in depth at the way discourses in men's magazines situate alternative performances of masculinity on parallel with the hegemonic one. Informed by Systemic Functional Linguistics (SFL), the study draws on a transitivity model to examine how discursive structures in magazines' texts produce counter hegemonic formations and build representations of non-normative performances.

\section{COUNTERING HEGEMONIC MASCULINITY}

Anthonio Gramci's (1971) analysis of class relations has contributed to the concept of hegemony, which refers to the leadership or dominance of one group over another, supported by legitimising ideas and norms. The concept of hegemonic masculinity came through prominence through the work of Connell $(1987,1995)$ and Connell and Messerschmidt (2005). It dictates for masculinity to be performed with the highest supremacy including holding and winning of power with potential formation or destruction of social groups. The legitimation of hegemonic construct is founded on the existence of subordinate masculinity, which is commonly characterized by race, religion, sexual orientation and socioeconomic background. Connell $(1995 ; 2002)$ explicates that in order for hegemonic masculinity to persist, there will be subordinate masculinity that involves men of the marginal position or the inferior 'others' (often occupied by lower class, coloured, homosexual men) who are denied access to the hegemonic position. Essentially, Donaldson (1993) encapsulates that the foundation of hegemonic masculinity is built upon "misogyny, homophobia, racism and compulsory heterosexuality" as its defining features (p.643). Since hegemony legitimises the hierarchical order of groups to maintain power structure, the concept has attracted criticisms. Scholars argue that the institutionalisation of hegemonic masculinity reinforces men's dominance over women and the marginalised groups of men through masculine practices such as aggressions and physical violence (Connell, 2002; Kaufman, 1994). Similarly, Kimmel (2018) further remarks that the adherence to hegemonic performances can become a destructive social force that continually divides, oppresses and prolongs crisis in men. Despite the criticisms, performances of hegemonic masculinity through depictions of stereotypical masculine models of men as the doer, explorer/adventurer, heroes, warrior /soldier, husband /provider, among others- remain to be foregrounded in mass media (Hatfield, 2010; Marshall, 2014). Representations of men as the authoritative figure, men being in control, and inept in parenting and domestic issues (refer Ricciardelli et al., 2010; Schmitz, 2016) are equally predominant. Early researchers have also remarked on magazine discourse centring on physical muscularity (Gattario et al., 2015) and hyper masculine conducts that endorse violence and aggression as acceptable expressions of masculine power (Bozkurt et al., 2015). Likewise, as shown in Mikorski and Szymanski 
(2017)'s study, lifestyle magazines such as Playboy and Maxim continue to advocate contents promoting sexual hedonism, bachelor life, pleasurable consumption subjecting women's bodies and rejection of domestication.

Nevertheless, with increased gender equality and shifting social norms, different variations of masculine models and ideologies can be seen emerging in the media spotlight. The representations of contemporary masculinity in the media are more sensible and inclusive, with contents carrying conscious messages that reflect diverse groups of men. Inclusive masculinity, an anti-hegemonic theory first put forward by Anderson (2009) describes the rapidly changing masculinity that exhibits diminished sexisms, homophobia, masculine violence and other traits of hegemonic masculinity. The theory addresses the growing societal space in which men no longer need to behave in hyper masculine ways to avoid being perceived as weak, feminine or gay (Anderson \& McCormack, 2018). Within this context, the emergence of masculinity in feminised context such as growing fascination over 'flower boy' (Yang, 2014) and soft masculinity (Lee et al., 2020) are observed to erode the long standing masculine hegemony. It is also evident that representations of machismo and hard masculinity are nearing expiry with public discussions about male vulnerabilities and fragile masculinity entering mainstream consciousness. In the social media sphere, talks about mental health, male depression and anxiety have become increasingly common in addressing toxic masculinity (Lavelle, 2020). Importantly, the socially constructed images of a rough and tough masculinity through embodied physical muscularity and emotional stoicism in particular, are actively renegotiated and replaced with softer traits encompassing values such as nurturance, empathy and sensitivity (Lee \& Lee, 2018). In media avenues, there has been an influx of representations surrounding fatherhood and caring masculinity, highlighting male agency in a spectrum of performances from household chores, child rearing duties and other feminised roles (Leader, 2019). Whilst in print media specifically, representations of men in caretaking roles often appear in parenting magazines (Schmitz, 2016) and print advertisement (Marshall et.al, 2014) and have been generally explored visually instead of at discursive level. As these identities signalled the instrumental shift in modern masculinity, another masculine architype that earned both popularity and notoriety in print media is metrosexuality (see Gough et al., 2014) This subtype of masculinity that developed alongside the gay liberation movement in late 1980s identifies metrosexuality as the embodiment of the new, sensitive men with fastidious grooming and interest in self-care (Simpson, 1994). Given the open acceptance for feminine pursuits and the emphasis placed on self-expression, the metrosexual has been regarded as the 'new age man' in which his presence is perceived to contest the constitution of hegemonic masculinity. In tracing the portrayals of alternative masculinities, this study is also shaped by recent research that examined homonormative and queer discourses in mainstream entertainment media that have portrayed more lesbian, gay, bisexual and transgender characters (Cabosky, 2015; McInroy \& Craig, 2017). Despite the sustained premises of heteronormativity in the media, the LGBT representations are mostly embraced in print media such as magazines aimed at queer community (Schwartz \& Andsager, 2011; Sonnekus \& Eeden, 2009). While narratives about homosexual men seeking inclusion and the coming out process are dominant discourses in queer magazines (Schwartz \& Andsager, 2011; Sonnekus \& Eeden, 2009), very few have analysed the homonormativity and construal of queer identity in heterosexual lifestyle magazines for men that typically sell idealised and coherent representations of hegemonic masculine values. As contemporary magazines move away from stereotypical contents and setting themselves apart from the masculinist, sexist and misogynist discourse, studies must not overlook in seeking to explore how this evolving platform develops and materialises non normative masculine identities in their discourse. The study argues that a consideration of alternative masculinities is necessary to understand the role that mainstream media discourse play in re-writing narratives of men and masculinities. In doing so, the study moves beyond 
the theorisation of masculinity as being fixed and patriarchal by considering the varied and complex nature of masculine identities.

Using Padgett's (2017) Alternative Masculinity Measure (ALT-M) checklist and corpus data developed from magazine texts in selected men's magazines, we address the development of multiple masculinities by selecting clauses that exhibit non-hegemonic or alternative forms of masculinity. We then discuss SFL's theory of transitivity and demonstrate the semogenic or meaning making process that construe male identities through different process types (i.e. material, mental, behavioural, relational). We then present the data, analysis and discussion, exhibiting first the results of ALT-M checklist, then identifying prominent patterns of alternative masculine identities (i.e. men as fathers, men as aesthetically concerned, men as vulnerable and men as homosexual) to show how transitivity choices embedded in texts exhibit different process selections at the lexicogrammatical level, which then enables counter hegemonic masculinities to manifest and unfold at the discourse semantic level. We conclude the paper with a summary of discussion, and primary findings' implications in terms of approaching masculinity from counter hegemonic perspective and analysing the alternative identity formation using transitivity.

\section{DISCOURSE AND IDENTITY PERFORMANCE}

How a subject fashions his or her identity can be realised in two ways - via a historical set of structures that regulate power upon identity or via interactions and discursive performances that construct one's identity (Benwell \& Stokoe, 2006). Identity in this study takes up the latter definition. Like Benwell (2003), Ricciardelli et al., (2010) saw power located in magazine discourse in which texts in magazines reflect social attitudes and maintain gender ideologies. Benwell and Stokoe (2006) emphasise that hegemony as a practice of power operates predominantly through discourse, in which ideas and cultural practices are circulated and accepted as normal or natural. For instance, the discourse of sexism is predicated on the idea that it is natural to disseminate stereotypical beliefs in society's minds that women are 'physically, emotionally and intellectually' weaker (Holmqvist \& Gjorup, 2006, p.93). Similarly, the notion of masculinity is planted through choice of words that assume and normalise men as leaders, thinkers, emotionally resilient, independent and courageous. In Foucault's 'discursive production of the subject' (1972), identity is viewed as the result of dominant discourses imbued in social practices (Benwell \& Stokoe, 2006, p. 30). Considering this, the idea of identity and masculinity can be said to be inscribed in available media discourse as magazines' texts. Foucault's view of identity as a discursive practice is similarly addressed by Judith Butler's (2011) theory of performativity, in which the basic premise of the theory constitutes gender as discursively produced with "performative agency through the repetitive 'iteration' of signs or act" (Butler, 1990, as cited in Benwell \& Stokoe, 2006, p. 33). In brief, the theory constitutes gender as not given or predetermined, rather an identity repeatedly constructed across time and through the body, often informed and enforced by social practices. Drawing inspiration from Butler's idea of performativity, this article understands masculinity as discursively produced and performed. Identity markers are derived through linguistic performance that communicate values, beliefs, affiliation, attitudes and feelings, and thereby works to show how masculinity is performed. This study attempts to explore constructions of masculinity through transitivity analysis that enables counter hegemonic formation to unfold at the discourse semantic level. Transitivity patterns allow for the subjects to be represented as acting or not acting, to highlight their dominance or passivity, in which case these representations 'can promote certain discourse and certain ideologies that are not overtly stated' (Machin and Mayr, 2012, p. 104). Paterson (2016) explains that the classification of the different kinds of processes in transitivity establishes differences in perspectives and 
viewpoints, resulting in an individuation process through which a man's sense of identity and comprehension of himself is conceptualised. The subsequent section demonstrates how transitivity plays a role that enables the narrative in men's magazines to produce counter hegemonic messages reflective of the 'New Men's' performances, through behavioural or attitudinal activities.

\section{TRANSITIVITY IN SYSTEMIC FUNCTIONAL GRAMMAR}

Halliday's Systemic Functional Linguistic (SFL) approach to critical discourse provides a structured and systematically dynamic means of investigating the meaning potential of texts. SFL concerns the functional use of language, which refers to the process in which people use language(s) as a social semiotic resource (Halliday \& Matthiessen, 1994). As a metalanguage and semiotic tool, the application of SFL has extended to various fields involving critical examinations of negotiation, organization, construction and construal of human experiences (Alameda-Hernandez, 2008). There are three 'functional components' of SFL that concern a different mode of meaning of clauses; - the ideational, the interpersonal and the textual. This study explores the ideational metafunction, in which language is used to make sense of the 'reality' and the construal of the inner and outer experience of 'goings on'; - how certain meanings are expressed, amongst other things. Reality, according to Halliday (1994), is built around "the processes of going on, happening, doing, sensing, meaning, being and becoming" (Halliday, 1994, p.106). Thus, the examination of transitivity in this paper focuses on the meaning of verbal elements in the clause in terms of what is being done (actions), what is happening (events), or what simply is (states). Table 1 outlines the process types and the different positions of participant:

TABLE 1. Transitivity process types, their meanings and participant roles (Halliday \& Matthiessen, 2014; p.311)

\begin{tabular}{|c|c|c|c|}
\hline Process Types & Category Meaning & $\begin{array}{l}\text { Participants, } \\
\text { directly involved }\end{array}$ & $\begin{array}{l}\text { Participants, } \\
\text { obliquely involved }\end{array}$ \\
\hline $\begin{array}{l}\text { Material } \\
\text { - Action } \\
\text { - } \quad \text { Event }\end{array}$ & $\begin{array}{l}\text { 'doing' } \\
\text { • 'Doing' } \\
\text { - 'Happening' }\end{array}$ & Actor, Goal & $\begin{array}{l}\text { Recipient, Beneficiary, } \\
\text { Client; Scope; Initiator; } \\
\text { Attribute }\end{array}$ \\
\hline Behavioural & 'behaving' & Behaver & Behaviour \\
\hline $\begin{array}{l}\text { Mental } \\
\text { - } \quad \text { Perception } \\
\text { - Affection } \\
\text { - Cognition }\end{array}$ & $\begin{array}{l}\text { 'sensing' } \\
\text { - 'Seeing', } \\
\text { - 'Feeling' } \\
\text { - 'Thinking' }\end{array}$ & Senser, Phenomenon & Inducer \\
\hline Relational & 'saying' & Sayer, Target & Receiver; Verbiage \\
\hline $\begin{array}{ll}\text { - } & \text { Attribution } \\
\text { - } & \text { Identification }\end{array}$ & $\begin{array}{l}\text { 'being' } \\
\text { - 'Attributing', } \\
\text { - 'Identifying' }\end{array}$ & $\begin{array}{l}\text { Carrier, Attribute } \\
\text { Identified, Identifier; } \\
\text { Token, Value }\end{array}$ & $\begin{array}{l}\text { Attributor; Beneficiary } \\
\text { Assigner }\end{array}$ \\
\hline Existential & 'existing' & Existent & - \\
\hline
\end{tabular}

As pointed out by Halliday and Matthiessen (2014), the selection and roles of the participant in the clause are largely determined by different process type selections 
encompassing the material, mental, relational, behavioural, verbal and existential. Material process represents the traditional definition of the verb as the 'doing word', involving the Actor, the goal and the beneficiary. Considered as the most salient type of process, material processes involve physical actions (running, cooking, scratching, etc.) that represent what is happening in the world, what actions and events are going on. Mental processes account for the processes of sensing that looks at what is going on in the internal world of the mind. The participants involved are the Sensor (the conscious being or the participant who senses) and Phenomenon (the participant being that which is perceived, reacted or thought about). The transitivity analysis in this aspect focuses on the male agent who is the sensor of mental processes categorized as 'perceptive' (hearing), 'affective (hating, liking, loving), 'cognitive' (understanding, thinking, imagining). Meanwhile, the relational process is divided into three sub categories namely; - 'Intensive', 'Possessive' and 'Circumstantial'. This process of being serves to characterise and to identify, that can occur either as attributive ( $a$ is the attribute of $\mathrm{x}$ ) or as 'identifying' ( $a$ is the identity of $x$ ) (Halliday, 1994). The process is realised by the copulating verb be or become that links the subject to complement. The relational process allows for the male entity to be construed in terms of the other, thus this element of transitivity serves to characterise and identify the male participant.

Between these processes, there are the minor processes types located at the three boundaries such as Behavioural (on the borderline between Material-Mental), Verbal (on the borderline of Mental-Relational) and Existential (on the borderline of Relational- Material); that are known as the 'border area' or described as 'fuzzy categories' (Halliday \& Matthiessen, 2014, p.216). The behavioural process for example, is considered as 'least distinct' in feature due to its absence of a 'clearly defined characteristics' (Halliday \& Matthiessen, 2014 p.248). Behavioural process shares some characteristics of the material and mental where the process is located at the boundary between material and mental, capturing the essence of psychological and physiological presentation of human experience (i.e., dreaming, smiling, crying, coughing, laughing, staring, dancing, etc). This type of fuzziness, as Halliday \& Matthiessen (2014) stress 'is a fundamental principle on which the (transitivity) system is based', indicating the fact that 'the world of our experience is highly indeterminate' (2014, p.217). A brief summary of the process types in Halliday's transitivity framework (Halliday, 1994) is as follows:

TABLE 2. Process types and participant roles (Halliday \& Matthiessen, 2014)

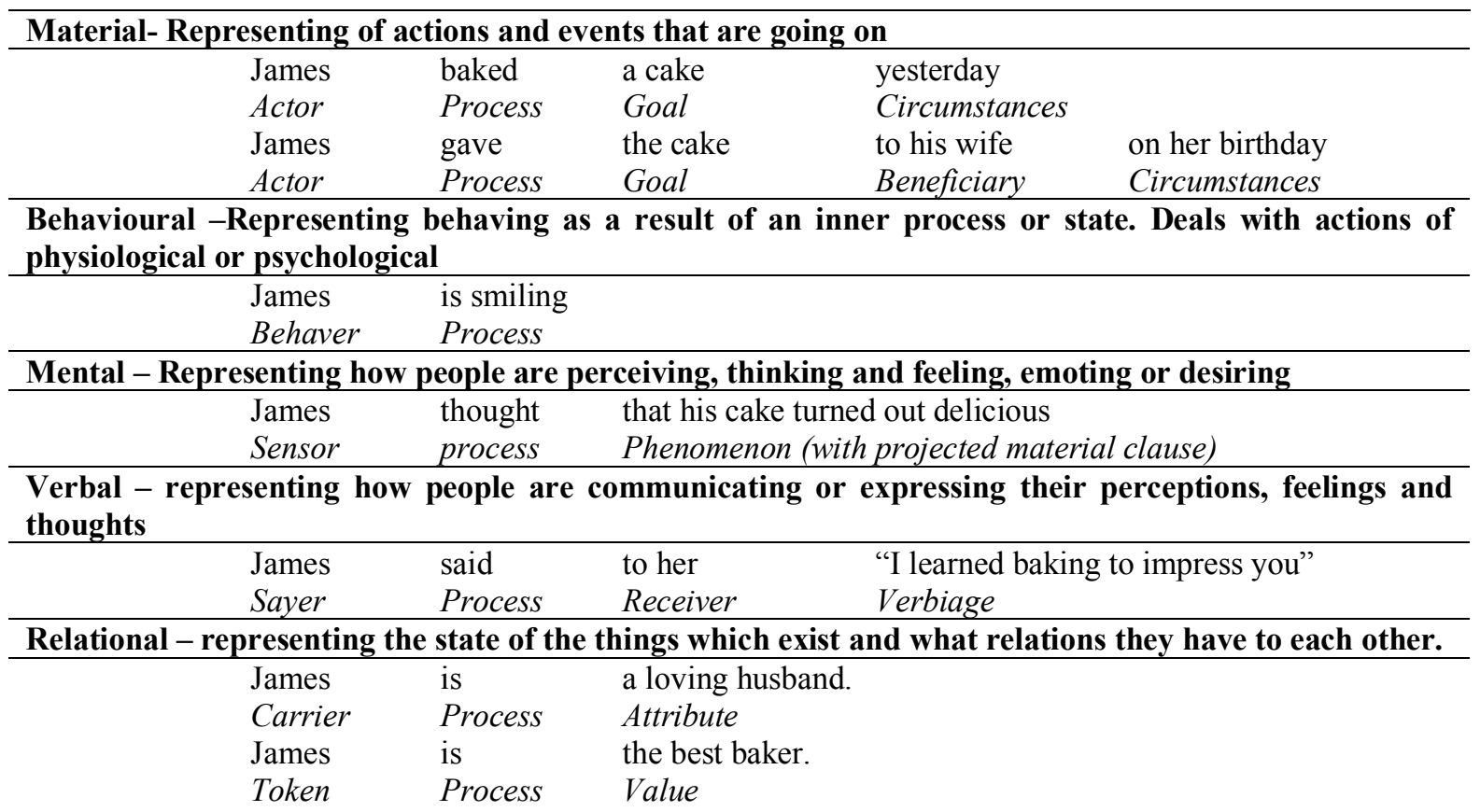




\begin{tabular}{cll} 
James & has & a cake \\
Possessor & Process & Possession \\
\hline Existential - representing & what exists in the world \\
\hline There & are & many burned cakes. \\
- & Process & Existent \\
\hline
\end{tabular}

Figure 1 demonstrates this study's conceptual framework linking Systemic Functional Grammar (SFG), transitivity and the encoding of representational experiences via magazines discourses in counter hegemonic formations:

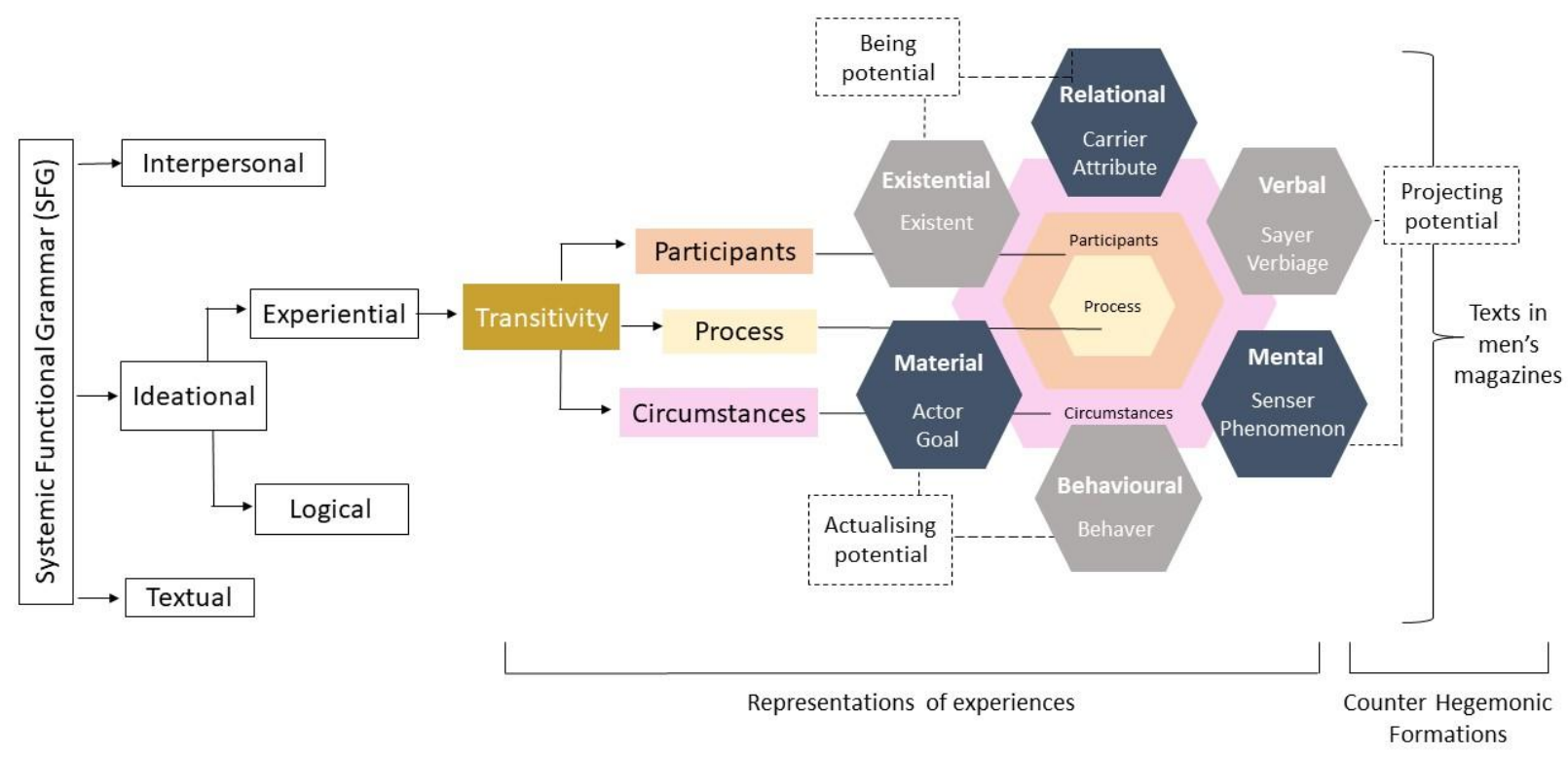

FIGURE 1. The role of transitivity in counter hegemonic identity constructions

Overall, the examination of transitivity choices in this study is motivated by the way male agency is represented through their actions, state of being or having. The instrumental application of transitivity also lies in its ability to distinguish the different kinds of processes and outline a set of grammar that provide a categorisation of masculine identity performances in texts that are not limited to hegemonic performances.

\section{METHODOLOGY}

\section{THE CORPUS}

The data, drawn from a larger corpus (584,600 word tokens) of an ongoing masculinity and multimodal discourse study was selected based on a series of checklist and inventory (i.e. Male Attitude Norm Inventory- II (MANI-II) (Luyt \& Foster, 2001), The Masculine Role Inventory (MRI) (Snell,1986) and Alternative Masculinity Measure (ALT-M) (Padgett, 2017).The selections include clauses that address non-traditional male roles and attributes, including representations of actions that are viewed as non-normative. This being said, texts that present male agency related to their action, state of being, state of having and circumstances that do not align with hegemonic masculinity or narratives were selected. The purposive sampling of information rich clauses related to the phenomenon of interest provides a relatively solid foundation for examining how language in men's magazines enable counter hegemonic formations. For the building of the corpus, 198 full articles from five digitally circulated lifestyle men's magazines titles published in 2016-2020 were analysed. The exponential 
growth of electronic and mobile newsstand has resulted in the decline of printed publications (Thurman \& Fletcher, 2020). Contents for the analysis were obtained digitally from five men's magazines sites that are available online for free. Online magazines or e-zines (electronic magazine) is opted instead of printed publications as they appeal more to readers of the digital era. Online men's magazines ensures a global circulation with no geographical barriers. This means that the magazine titles selected for the corpus are not only accessible to Malaysian readers but are exposed to massive visibility and broad readership, ensuring the representativeness of findings in this study. This extensive level of exposure allows for massive visibility and endless possibility, making electronic version relevant, and a great data extraction ground. Also, digital extraction ensures data accuracy during the process of data transfer to the corpus software instead of manual scanning from printed copies that can potentially compromise data accuracy. The magazines from which the data were extracted include $G Q$, Esquire, FHM, August Men, and Men's Folio. The titles selected for data analysis are men's magazines categorised among twenty most popular titles in 2014-2018 according to the media database Cision Comunication Cloud. According to figures released by the Professional Publisher Association in 2019, lifestyle magazines such as GQ has 28 million readers and Esquire 19 million readers, making them among the tiles leading the digital market. Furthermore, the researcher believes that changes in social trends and representations of men are observable in these titles. GQ or Gentleman Quarterly, for instance, offer a luxurious and appealing content through strong visuals and sophisticated journalism addressing various aspects of men's passion, while Esquire aspires to explore the male universe as a coach and friend to guide men in all situation; -fashion, grooming, watches and technology, politics, careers, self-improvement and relationship. This makes lifestyles magazines a versatile site for the exploration of men and masculinity.

\section{CORPUS-BASED ANALYSIS}

The analysis follows an approach adapted from Biber et al. (2007) to achieve generalizable corpus based descriptions of discourse structure. In this 'top-down' approach, seven step analytical processes will be applied to texts in corpus. Drawing from the approach, this article focuses on the transitivity choices and the functional purposes of texts as the starting point for understanding how transitivity affects meanings of masculinity and the overall transitivity tendencies reflective of the corpus. First, to understand how texts are structured the way they are, the analytical process is developed. This allows for a determination of different functional types of discourse units that serve a particular communicative function. Texts are then segmented and classified into discourse units. Here, texts are first analysed for transitivity using tables to categorise all clauses into their constituents. Next, all texts are analysed in terms of their lexical and grammatical characteristics with particular focus on classifications of verbs. The description of these classifications is conducted in terms of the typical lexical and linguistics characteristics, focusing primarily on the verb elements to provide the basis of the transitivity analysis. The texts are identified for patterns and selections of process type across the corpus, which reveal how counter hegemonic identities are enabled at discourse- semantic level, particularly in terms of how magazine text draw on the male agent as an active participant to represent alternative masculine practices in a way that conceal hegemonic performances through the lexicogrammatical choice. The analysis then focuses on texts structures that analyse complete texts as sequences of discourse units shifting among the different functional types. Finally, the discourse organisational tendencies will be explored, through which the general verb patterns including frequency and statistical significance are identified. The final process is applied while simultaneously carrying out an in depth enquiry into how verb components and transitivity choices are used in context and, as such, what potential meanings 
are derived from their usage to unveil an underlying ideology of men's magazines or, otherwise, the entity responsible for the actions in verb processes. Accordingly, the main questions anchoring this study are:

1. What elements of transitivity are employed in constructing counter hegemonic masculinities in men's magazines?

2. How do men's magazines facilitate the enactment of counter hegemonic performances via different transitivity process types?

3. What type of alternative masculinities are represented in the corpus?

\section{ANALYSIS AND DISCUSSION}

This section presents the examination of transitivity that identifies the kind of lexicogrammatical and semogenic (meaning-making) strategies employed in magazine texts to produce counter hegemonic identities. Inspired by the Alternative Masculinity Measure (ALTM) (Padget, 2017) and based on analyses of the corpus, a list of semantic categories of quality for new and alternative masculinities are constructed. Table 3 shows transitivity patterns of counter hegemonic performances across the corpus that depict the male participant in various social practice representations.

TABLE 3. Transitivity analysis of agentive male participant by semantic categories in all clauses

\begin{tabular}{|c|c|c|c|c|c|c|c|c|c|c|c|c|c|c|}
\hline \multirow{3}{*}{$\begin{array}{l}\text { Process } \\
\text { Type }^{\mathrm{a}}\end{array}$} & \multicolumn{14}{|c|}{ Semantic categories of social practice representation } \\
\hline & \multicolumn{2}{|c|}{$\begin{array}{l}\text { Emotional } \\
\text { expressiveness }\end{array}$} & \multicolumn{2}{|c|}{$\begin{array}{l}\text { Homo } \\
\text { normativity }\end{array}$} & \multicolumn{2}{|c|}{$\begin{array}{l}\text { Gender } \\
\text { Egalitarianism }\end{array}$} & \multicolumn{2}{|c|}{$\begin{array}{l}\text { Fatherhood } \\
\text { and family }\end{array}$} & \multicolumn{2}{|c|}{$\begin{array}{l}\text { Grooming } \\
\text { and } \\
\text { aesthetics }\end{array}$} & \multicolumn{2}{|c|}{ Others } & \multicolumn{2}{|c|}{ All categories } \\
\hline & $\mathrm{n}^{\mathrm{b}}$ & $\%^{\mathrm{c}}$ & $\mathrm{n}$ & $\%$ & $\mathrm{n}$ & $\%$ & $\mathrm{n}$ & $\%$ & $\mathrm{n}$ & $\%$ & $\mathrm{n}$ & $\%$ & $\mathrm{~N}$ & $\%$ \\
\hline Material & 9 & 10.11 & 16 & 36.36 & 8 & 14.81 & 25 & 27.78 & 38 & 31.93 & 12 & 28.57 & 108 & 24.66 \\
\hline Relational & 24 & 26.97 & 9 & 20.45 & 29 & 57.7 & 37 & 41.11 & 44 & 36.97 & 18 & 42.86 & 161 & 36.76 \\
\hline Mental & 32 & 35.96 & 7 & 15.91 & 14 & 25.93 & 15 & 16.67 & 12 & 10.1 & 6 & 14.29 & 86 & 19.63 \\
\hline Behavioural & 17 & 19.1 & 8 & 18.18 & - & - & 4 & 4.44 & 14 & 11.76 & 2 & 4.76 & 45 & 10.27 \\
\hline Verbal & 6 & 6.74 & 4 & 9.09 & 2 & 3.7 & 7 & 7.78 & 11 & 9.24 & 4 & 9.52 & 34 & 7.76 \\
\hline Existential & 1 & 1.12 & - & - & 1 & 1.85 & 2 & 2.22 & - & - & - & - & 4 & 0.91 \\
\hline $\begin{array}{l}\text { Clause } \\
\text { totals }\end{array}$ & 89 & & 44 & & 54 & & 90 & & $\begin{array}{l}11 \\
9\end{array}$ & & 42 & & 438 & \\
\hline$\%$ of text & 20.32 & & 10.05 & & 12.33 & & 20.5 & & $27.1^{\prime}$ & & 9.59 & & 100 & \\
\hline
\end{tabular}

Throughout all text types, magazines discourse represents male participants most frequently as; - 1) establishing their identity and attributional description via relational processes $(36.76 \%), 2)$ engaging in material activities $(24.66 \%), 3)$ projecting cognitive functions as thinking and sensing (19.63\%) and 4) performing behavioural activities $(10.27 \%)$. As can be seen the dominant transitivity process by far is related the relational category, while verbal and existential processes account for the least occurring processes at around $7 \%$ and $1 \%$ respectively, pointing out to the minor role the two processes play in counter hegemonic formations.

Across all corpus, magazine texts represent agented male participants in various performances: 1) paying attention to personal grooming and improving their own appearance ( $27 \%$ of all clauses), 2) men taking up fathering roles and exercising a family oriented 
masculinity such as childcare, doing household chores and other domesticated activities (about $20 \%$ of all clauses), 3) expressing emotions (about 20\%), 4) projecting gender egalitarian attitudes such as respect and equalities that dissolve gender differences (about 12\%), 5) supporting queer society and being confident of one's sexuality (about 10\%). Collectively, these account for almost $90 \%$ of the transitivity process types and textual representational functions. Other semantic categories of social practice representations include counter hegemonic performances related to religion and belief, green and eco awareness and health and fitness regimes which account for $10 \%$ of overall clauses. A list of semantic categories of counter hegemonic identity with their definitions, clause examples and transitivity choices can be found in Appendix.

\section{PATTERNS OF COUNTER HEGEMONIC MASCULINITIES}

In this section, we demonstrate how clauses and transitivity choices realise experiences and position men's agentive role in different process types. As outlined in Table 1, this exploration addresses the development of four alternative male identities prominent in our findings which relate to themes of 1) fatherhood and family, 2) grooming and aesthetics, 3) emotional expressiveness and 4) homonormativity. The discursive analysis of each of these categories is presented with example clauses from the corpus. Halliday's Transitivity tool was used to interpret latent narratives which communicate specific meanings that construe non-hegemonic identities.

\section{1) Fatherhood and Family}

\section{CARING AND PATERNALLY ENGAGED FATHERS}

In significant instances across the texts, men's magazines discursively present the male agency in roles and performances related to fathering and parenting. There was a salient pattern of material processes $(27.78 \%)$ representing men as engaged fathers in the family. In example [1], the process 'do' that presents the participant as the doer (actor) is realised by the verb raised. Other material processes such as 'wake up every night', 'prepare his milk' and 'changed his nappies' were uttered by the agented male participant, demonstrating his competency in performing conventional motherly duties.

[1] I raised him - I am the father and I am the mother. I remember when he was a baby, I had to (Material) (Relational-identifying) (Mental- cognitive) wake up every night to prepare his milk. I changed his nappies, I was his mum for a year. (Material) (Behavioural) (Behavioural) (Relational-identifying)

Example [2] below challenges the myth of absent fathers. Through behavioural processes struggle, reproach and write, it could be suggested that the male individual in this profile is determined to be involved into his children's lives as a primary caregiver. 
I struggled quite a lot with my children because I think this new generation is very different (Behavioural) (Mental-Cognitive) from ours. They are constantly on their phones and tablets and it's really hard to talk to them (Verbal) so I sometimes write letters to them to tell them about life or what I think, or when I have to (Behavioural)

(Relational)

reproach them somehow because they are so stuck on their gadgets [...]. (Behavioural)

The example above demonstrates an instance in which a mother's role as a caring confidant is emulated. The verb choices in example [2] suggest a shift in fathering, away from traditional forms of masculinity, termed as 'caring masculinity' according to Hunter et al. (2017).

The transitivity processes in example [3] below deconstruct the normative views of child rearing as a one parent duty - the mother's. The agency of the male participant is depicted in various transitivity processes that presented him as highly involved in child rearing duties. In this non-stereotypical depiction, the clause highlights a father's involvements in a diverse range of family structure.

[3] Now that Hardy is home, he's spending as much time as possible with his children and to add (Relational) (Behavioural)

to the challenge, he's two days into potty-training his two-and-a-half-year-old.

(Circumstantial)

In example [4], the material action 'woke up' centres around the routine care of an infant. The man's confession of his compulsive behaviours and constant obsession of 'checking' whether or not his son is breathing reflects the anxiety that stems from the excessive bond and attachment with the infant (Moller et al., 2015). This behavioural process indicates the experience of a new parent that results from fear and worry which affects women than men (Williams \& Koleva 2018).

[4] I woke up in the middle of the night when he was sleeping next to us in the first few weeks just (Material)

checking if he was breathing.

(Behavioural)

\section{[5] I don't think I'm that strict with Joseph, I don't know why (Mental) \\ (Mental)}

Unlike the traditional representations of fathers as authoritative and disciplinarian figures, the shifting representation in example [5] above suggests that modern men are adopting a new model of fathering. The clause reflects the agented male participant as a loving and affectionate father who has a strong emotional bond with his son, spends quality time and builds his influential roles in his son's life. This changing representation in media actively calls for men to redefine and reject the culturally prescribed understanding that built them around the confining image of fathers.

Overall, in a number of clauses relating to parenting and family, men are seen in a position of primary caregivers who, in most occasions, prioritised their children and adopted the traditionally feminine attributes such as nurturance, empathy, domestication and caring. The findings redefined men in opposition to dominance, emotional stoicism or incompetence. From the data too, it can be deduced that the increased attention on nurturing and child rearing, 
along with the growing emotional connection with their children might alter the unequal gender dynamic within a family. Overall, the transitivity patterns construct 'caring masculinity' that opposes the hegemonic ideas of men as domineering and emotionally detached father figures.

\section{2) Grooming and aesthetics}

\section{MALE VANITY AND PUBLIC SELF-CONSCIOUSNESS}

Next, the analysis of transitivity patterns reveal instances of actions related to male vanity and physical preening. Excerpt [6] below shows the male subject giving attention to his appearance, body, hair, face and skin, realised through several process types.

[6] I haven't got an hour to spend in the morning on my complexion. I have four kids. I

$$
\text { (Behavioural) (Relational- possesive) }
$$

want it simple. I get up, shower, sometimes cleanse depending on what I did the night (Mental) (Material) (Material)

before. I moisturize always; I use some eye cream and some hand cream. Hair, I just (Material) (Material)

get out of the shower and brush some product in. I do like a thickening shampoo.

(Material)

(Mental)

These verbs describe the male subject's grooming routines through two mental processes want and like and actor of six material processes realised via the verbs get up, shower, cleanse, moisturise, use and brush. The material processes represent the male subject as the doer of beautification and enhancement activities. These material processes also reveal the nature of his action that emphasizes his physical appearance and attention to different parts of his body through processes such as spend (on complexion), cleanse and moisturize (face), brush (hair), use (eye cream).

A closer look at the use of mental processes shows that the male participant is determined to keep up with his routine despite the busy schedule. Also noticeable in the clause is the unfavourable view of age as a process that reduces physical attractiveness. The narrator uses the third point of view you (e.g.: when you get to a certain age) to actively involve the readers in his narration. The material action brush (some product in) whereby the male agent admits to preferring a thickening shampoo, and material action moisturise followed by always suggest an action he performs unfailingly to preserve his youth. Example [7] below contains actions representing the agented male participant as a hyper groomed metrosexual.

\section{[7] Joey describes how he will pluck stray eyebrow hairs and avidly polish his shoes (Material) (Material) before stepping out of the house.}

The material processes described attention given to his aesthetics. In contrast to the verb 'shave' or 'wax', the author's verb choice pluck (stray eyebrow) presents the narrative of the doer as a detail oriented individual. Plucking eyebrows over other brow grooming methods suggests that he will only settle for pristine brow. What can be implied from the material action pluck is the amount of pain, time and effort that the doer is willing to invest in to maintain his immaculate appearance. Also, through the writer's lexical choice in describing the doer's engagement in keeping his shoes shiny via the pairing of a finite material process polish with the preceding adverb avidly, constructs the nominal group as a male dandy who wants to appear impeccably-groomed. 
The nominal group in clause [8] exhibits his awareness of his attractiveness, via the behavioural process gazing:

$$
\text { "Do you think I will stay } 21 \text { forever if I use this (cream)?" Essex asks me, gazing for }
$$

(Behavioural)

a few moments at his own reflection in the mirror.

The material process use represents a routine in facial care and anti-aging procedure that surpasses the traditional domains of haircuts and shaving. Meanwhile, the behavioural process of gazing at his own reflection in the mirror can be seen as an act of admiring his favourite body part - his face. The behaviour also alludes that maintaining an immaculate physical appearance is a key prerogative. Gazing reveals a form of counter hegemonic identification related closely to self-vanity, an attribute that traditionally linked to deviant masculine behaviours. However, with increased access to mass media and consumption culture, vanity and public self-consciousness are beginning to define modern masculinities (Gough et al., 2014). This narrative is also in line with previous studies that addressed the possibility of male gender as the vainer sex than women (Stich, 2015).

Another significant pattern in the clause is the assignment of the male participant into the roles of an actor and a goal. In example [6], the participant is mapped as an actor applying direct action to his face, eyes and hair. So does the actor in example [7] who performs a direct action pluck to his bodily feature 'eyebrow'. The transitivity processes construed attempts to create a different look or enhance their appearance. By doing so, they become the goal of their own self-interested actions. Portrayals of the participant as both actor and goal, or initiator and receiver construes him as a man engaging in self-preening, reflecting the paradox in male beauty quest, where vanity have given birth to the rise of highly confident metrosexual male. This implies the changing narrative in masculinity that not only rejects the stereotypes of vanity as essentially unmanly, but constructs a new masculine identity that is empowered by feminine qualities.

\section{3) Emotional expressiveness}

\section{VULNERABLE MEN AND FRAGILE MASCULINITY}

Studies have shown that there is a certain level of allure about vulnerable and highly sensitive men (Orloff, 2017). Despite opposing the categorical imperatives of traditional masculinity, these socially desirable traits forged a new paradigm in the evolution of masculinity, marking the birth of empathic men who are strong and sensitive, intuitive and powerful. Examples [9] [14] below present men's experiences to reality relating to personal insecurities and vulnerabilities that are realised through material, behavioural and relational processes of circumstantial. In all these clauses, one notable transitivity pattern worth exploring relates to the behavioural process of 'crying', an act that is often perceived as a sign of weakness in men. Some examples extracted from the corpus include:

[9] I was so distraught when the marriage failed - I cried all the way home. I didn't see it (Relational-circumstantial) (Behavioural) (Behavioural) coming; it shook my world and I was lost.

(Relational-circumstantial)

[10] I cried giving one to the aforesaid brother-in-law. (Behavioural) 
[11] To this day I cry at every ceremony even those where I am just a plus one. (Behavioural)

[12] I cried like a starving newborn, while watching Danny Boyle's sequel [...]. I still blubbed like (Behavioural) (Behavioural) a baby. The movie caught me at the right time, right age.

(Behavioural)

[13] He's almost crying in all the serious scenes. He sounds like he's always on the verge of losing it.

$$
\text { (Behavioural) (Relational) }
$$

[14] He wore his lucky scarf, he brought four boxes of tissues. He sat in the same spot he always (Material) (Material) (Material) did-among people he's known for a decade and who were no stranger to seeing him cry.

Clauses [9] to [14] construct the male as someone who cries, formed from their own and others' point of view. The verb cried - a behavioural process between material and mental - is an act driven and conceived by internal emotional tension, and released externally. The male senser in [9] confessed that he cried when his marriage failed. Whereas, in [10] and [11], the male subjects' cried at weddings and [12] and [13] show that the male participants cry while watching movies. In [14], the material and behavioural variants occurred within the same clause, denoting the male participant as sensitive and soft-hearted. What can be interpreted in these clauses is that crying is not uncommon and that some men are letting others witness this unguarded side of their personality. As crying becomes unconventional, this behaviour dismantles the rigidity of gender performances and cultural expectations that dictate men to be emotionally restrained.

Meanwhile, in [15] below, the transitivity patterns present the male participant as emotionally vulnerable. The clauses break masculinity stereotypes that connect men to stoicism:

[15] I'm not a violent guy, I'm emotionally very sensitive [..] and quite vulnerable! But I pretended. (Relational- Intensive) But my difficulties probably manifested from the fact that I am sensitive. And trying (Relational- Intensive) (Behavioural) to explain that brittle, slightly feminine quality that I have, because there's a physicality about (Verbal) (Relational- Possessive) me that is masculine, and then also I'm quite bitchy..."

(Relational- Intensive)

In excerpt [15] above the relational process pretended creates the understanding that the man fears being questioned if he does not present himself as assertive, strong and selfassured, despite desiring to be vulnerable. This pattern of behaviour supports studies by Way et al. (2014) that reported the root in male crisis stemmed from men's need to adhere to masculine norms and appearing tough. Also worth noting is a string of adjectives indexing femininity such as sensitive, vulnerable, brittle and bitchy that contradicts the lexical item masculine. This juxtaposition made his identity complex, yet unique. In another observation, the man identifies himself as 'emotionally very sensitive' and 'quite vulnerable'. The representation of the male subject as heavily masculine in physicality yet 'quite vulnerable' 
and 'very sensitive' emotionally, constructs the 'New Man' masculinity, connoting a more progressive masculinity of sorts.

Similarly, the nonconformist views of masculinity were evident in the discourse that presented the agented male participant discussing personal shortcomings and weaknesses publicly. In clauses [16] to [18], the male agent is portrayed as coming to term with his incapacity to fulfil masculine expectations. In examples below, the nominal group emerges as a central but problematic character in which his crisis is demonstrated via the use of verb processes related mostly to mental and emotional experience:

[16] I wanted it to be more like: 'I'm sat in a helicopter and I'm shitting my pants. (Mental- desiderative)

(Material)

[17] I'm a battle-hardened veteran of $x$ amount of tours and I'm still scared. (Relational)

(Relational)

[18] He got a job in corporate project management but hated it. Finally, he found himself on a (Relational- Attribute)

clifftop, considering suicide. "Whether I was gonna jump or not, I don't know," he reflects (Mental- cognitive) (Material) (Mental-cognitive)

now. "But I think that moment needed to happen. I needed to be standing there (Mental-cognitive)

(Material)

contemplating that maybe the best thing for me was to kill myself.

(Mental-cognitive)

(Material)

The male subject is attributed to several types of verb processes, with multiple occurrences of mental processes such as wanted, think, considering, contemplating, and evaluative attribute that overlaps with mental but serves as a relational process instead, such as hated. In all mental processes, the nominal group is positioned as the 'focaliser' or 'reflector' of the sensing process. This allows the readers to align with his thoughts, by giving access to his fear and worries. The excessive use of mental processes relating to desiderative (wanted) and cognitive (considering, contemplating, know) indicate that while he is overwhelmed with self- doubt, he is conscious and aware of his mental experience. In [18], whereby instances of material processes occur, they tend to reflect a self-destructive behaviour which is observable via verbs standing (on a clifftop), jump and kill (myself). This suicidal thought, often a result of depression and anxiety, is also a form of identity disturbance resulting from men's constant need to adhere to masculine gender norms (see Granato et al., 2015).

It is also worth noting that some process types emphasise on the equivalence and oppositional concept of good/bad or strong/weak. For instance, the phrase 'I'm a battle hardened veteran' is contrasted with the phrase 'I'm still scared', presents an interesting oppositional concept. They invite the readers to experience certain feelings and emotions that the participant experiences such as anxiety and fear. Also, drawing from Fairclough's concept of 'simulated equalization' (1989, p.221), the technique attempts to put the verbal producer on 'an equal footing' (p.221) with the reader. For instance, the behavioural verb 'shitting' (my pants) convey the understanding of excruciating fear and the relational process of attribute 'hated' (the job) that general readers could identify with. The lexical items can have significant ideological ramifications. They not only present the participant's state of mind or the complexity of his identity but validate that fragile masculinity is a real concept. 


\section{4) Homonormativity}

\section{QUEER VISIBILITY AND HOMOSOCIAL DESIRE}

There were 38 instances of textual representations of queerness recorded across the corpus. Examples [19] to [22] indicate the male agent negotiating homonormative behaviours with various transitivity choices:

[19] Dozen heterosexual male celebrities have kissed each other in a campaign in support (Behavioural) of LGBT equality. [..] While some appear reticent, others seem to passionately

embrace the task at hand.

(Relational)

(Behavioural)

[20] "It was the first time I've kissed a man". Reckermann told Spiegel Online about (Behavioural)

smooching fellow athlete Brink. Both men said while they'd prefer to kiss their wives, (Behavioural) (Behavioural) they didn't hesitate to join the campaign, "It's a very, very important issue. We saw it (Mental) (Behavioural) as our duty to use our popularity as Olympic athletes. We wanted to make clear that (Behavioural) (Mental) there is no place for homophobic thoughts.

Analyses of the above samples indicate a progressive representation of homosexual male participant. The recurring instances of behavioural processes kiss, kissed and smooching that denote a process of touching and caressing with the lips as a sign of sexual desire between male participants bring in the narrative that intertwines homonormative behaviours to masculinity. Also evident in the sample is the sexual orientation of the participants that was specifically emphasised in the clause. They were described as heterosexuals who 'prefer to kiss their wives'. This reinforcement of the participants' heterosexuality creates a narrative that frame homosexual behaviours within the hegemonic paradigm.

In another representation of homosocial norm, the transitivity choices depicting the male agency occurred more frequently via mental process as opposed to other types of processes:

[21] I'd go on gay chatrooms but that was just a faceless conversation with someone who could have (Material)

been anyone. It didn't make me feel any better. I just didn't think there was anyone else out (Mental-Emotive) (Mental-Cognitive)

there who was like me. I think if I'd had friends who were gay when I was growing up, my life (Mental-Cognitive) (Relational)

(Relational)

would have been so different.

Examples [21] presents three instances of mental processes, one instance of material and two instances of relational processes that construe being (was) and having ( $h a d)$ occurring simultaneously, all of which have allowed the readers to establish the connection with the male participant's loneliness. While they presented an internal view of him, the use of mental processes 'feel' and 'think' present the processes of consciousness that are construed in terms 
of desiderative and cognitive awareness, in which these processes are built upon his need to affiliate.

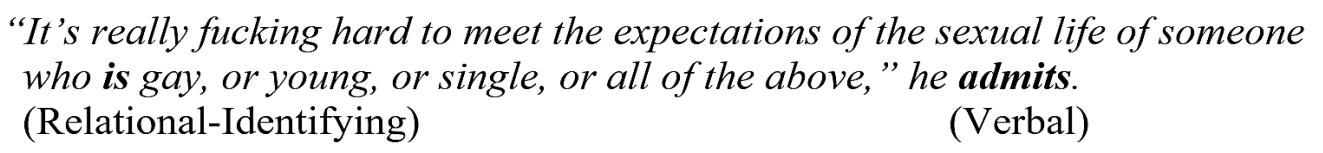

"It's really fucking hard to meet the expectations of the sexual life of someone who is gay, or young, or single, or all of the above," he admits.

(Relational-Identifying)

(Verbal)

Likewise, the development of homosexual as an identity is evident in example [22] above with the agented male participant openly self-identifying himself as gay. The relational process of identifying realised via the be verb is indicates a progressive awareness of homosexual behaviour. Such self-labelling, while it validates an individual self-acceptance, mark the coming out processes for homosexual men, which can be challenging for individuals who question their sexuality and LGBT identity. Further supporting Dhaenens (2013) argument that media representations of homonormativity is central in declining cultural homophobia and homohysteria, thus helping foster an inclusive vision of masculinity. Overall, the transitivity patterns and lexical choices employed in approaching queerness in mainstream media domain demonstrate the inclusive stance that heteronormative men's magazines are adopting to normalise homosexuality.

To summarise, the analysis of counter hegemonic performance in men's magazines discourse has revealed that the male agency appeared predominantly in various transitivity processes that construct them in different alternative identities. Detailed corpus analyses showed that men were portrayed more in the state of being (relational processes $36.76 \%$ ), doing physical actions (material processes $24.66 \%$ ) and expressing feelings and emotions (mental processes $19.63 \%$ ) rather than behaving (behavioural processes 10.27\%) and speaking (verbal processes $7.76 \%$ ). In relational processes, the male agency was found to be repeatedly presented in intensive and identifying processes relating to 'fatherhood and family' as well as 'grooming and aesthetic' instead of relational processes that showed what they possessed or their circumstances. Where material process is concerned, men's actions tend to be present in semantic categories concerning homonormativity and personal grooming. In transitivity instances of mental processes, men were featured to have an aptitude in 'emotional expressiveness' and believed in 'gender egalitarianism'.

\section{CONCLUSION}

This study has demonstrated the usefulness of transitivity as a viable model to explore the formation of counter hegemonic identities in magazine discourse, via a systematic description of lexical choice and pattern of processes to encapsulate identity performances and social behaviour that are not always explicit for readers. Data from the corpus analyses revealed that transitivity processes constructed men in emerging and non-hegemonic identities such as the competent father, the hyper groomed, the vulnerable and the homosexual. In this process of reaffirmation of new alternative masculinity, it is essential to take into account the plurality in masculinity. Some of the most progressive identities developed in the data have presented the male agency in non-normative circumstances and roles surrounding fatherhood, domesticated involvement, emotional insecurities, aesthetic concerns and homonormativity that were previously assumed as secondary or characteristics of deviance. Evidently, the representations of men doing away with stereotypes and expectations were observable in the findings with the recurring use of mental and behavioural processes, particularly via verb realisations such as feel, wish or cry. Connell, Kimmel and others have emphasised the imperative needs for scholars of men and masculinities to rethink traditional constructs of masculinity and challenge the dominant norms in order to balance gender equilibriums. This being said, our findings have 
shown that magazines texts have narratively countered hegemonic performances by representing alternative masculinities to co-exist or perhaps rise above the dominant ideals in the hierarchy of masculinities.

Despite scholars advocating for transitivity to be adopted more often in the critical examination of discourse, the utilisation of SFG and transitivity as a tool is not without its limitations. The obscurity of SFG and transitivity specifically, lies in the ambiguity of its categories and processes as two or more process types may be functioning at the same time (Bartley, 2017). The verbs with more complex meanings may extend into more than one process category, resulting in overlapping processes. Therefore, it should be addressed that there will be verb groups appearing in more than one process type although they are treated following Halliday and Matthiessen's (2014) categorization. For this reason, transitivity analysis in this paper employed only options listed by Halliday and Matthiessen (2014) for the classification of verbal process sets in ensuring internal consistencies. As with the implication, the corpus based functional analysis with the help of concordancing technique was valuable in unravelling hidden patterns of male identities in high frequency words. Importantly, while this study offers the intersectionality between transitivity and performative identity as a way of interrogating counter hegemonic formations, the findings offer broader acceptance for alternative models of manhood, paving the way for more holistic and evolved ways of doing masculinity. On this note, the popular culture as men's magazines is perhaps a realm that can begin to open up discursive avenues of alternative performances of masculinity and liberate men from stereotypes for a fairer society.

\section{ACKNOWLEDGMENTS}

This work has developed out of a transitivity chapter in a $\mathrm{PhD}$ dissertation about multimodal constructions of new masculinities in magazine discourses. We would like to express our sincere gratitude to the reviewers for their comments and insights that greatly improved the manuscript.

\section{REFERENCES}

Alameda-Hernández, Á. (2008). SFL and CDA: Contributions of the analysis of the transitivity system in the study of the discursive construction of national identity (case study: Gibraltar). The Linguistics Journal, 3(3), 160-175.

Anderson, E. (2009). Inclusive masculinity: The changing nature of masculinities. London: Routledge.

Anderson, E., \& McCormack, M. (2018). Inclusive masculinity theory: Overview, reflection and refinement. Journal of Gender Studies, 27(5), 547-561.

Bartley, L.V. (2017). Transitivity, no stone left unturned: Introducing flexibility and granularity into the framework for the analysis of courtroom discourse. Unpublished doctoral dissertation. University de Granada

Benwell, B. (2003).Ambiguous masculinities: heroism and anti-heroism in the men's lifestyle magazine. In Masculinity and Men's Lifestyle Magazines, 151-168. Oxford: Blackwell.

Benwell, B. \& Stokoe, E. (2006). Discourse and Identity. Qualitative Research in Psychology, 4(3), 261-262.

Biber, D., Connor, U., \& Upton, T. (2007). Discourse on the Move: Using corpus analysis to describe discourse structure. Amsterdam: Benjamins.

Bozkurt, V., Tartanoglu, S., \& Dawes, G. (2015). Masculinity and violence: Sex roles and violence endorsement among university students. Procedia-Social and Behavioural Sciences, 205, 254-260. 
Brescoll, V. L., \& Uhlmann, E. L. (2008). Can an angry woman get ahead? Status conferral, gender, and expression of emotion in the workplace. Psychological science, 19(3), 268275.

Brod, H. (2018). The Making of Masculinities (Routledge Revivals): The New Men's Studies. New York: Routledge.

Butler, J. (2011). Gender trouble: Feminism and the subversion of identity. London: Routledge.

Cabosky, J. (2015). "For Your Consideration" A Critical Analysis of LGBT-Themed Film Award Campaign Advertisements: 1990-2005. Journalism History, 41(2), 73-84.

Carabí, À., \& Armengol, J. (Eds.). (2014). Alternative masculinities for a changing world. New York: Palgrave Macmillan.

Connell, R. W. (1987). Gender and power. Sydney: Allen and Unwin.

Connell, R.W. (1995). Masculinities. Cambridge, UK: Polity Press.

Connell, R. W. (2002). On hegemonic masculinity and violence: Response to Jefferson and Hall. Theoretical criminology, 6(1), 89-99.

Connell, R. W., \& Messerschmidt, J. W. (2005). Hegemonic masculinity: Rethinking the concept. Gender \& society, 19(6), 829-859.

Dhaenens, F. (2013). Teenage queerness: negotiating heteronormativity in the representation of gay teenagers in Glee. Journal of Youth Studies, 16(3), 304-317.

Donaldson, M. (1993). What is hegemonic masculinity?. Theory and society, 22(5), 643-657

Espelage, D. L., Hong, J. S., Merrin, G. J., Davis, J. P., Rose, C. A., \& Little, T. D. (2018). A longitudinal examination of homophobic name-calling in middle school: Bullying, traditional masculinity, and sexual harassment as predictors. Psychology of violence, 8(1), 57-66.

Fairclough, N. (1989). Language and power. London and New York: Longman.

Foucault, M. (1972). The Archaeology of Knowledge (A.M. Sheridan Smith, Trans.). New York: Pantheon Books.

Fowler, R. (1991). Language in the News: Discourse and Ideology in the Press. London and New York: Routledge.

Gattario, K. H., Frisén, A., Fuller-Tyszkiewicz, M., Ricciardelli, L. A., Diedrichs, P. C., Yager, Z., \& Smolak, L. (2015). How is men's conformity to masculine norms related to their body image? Masculinity and muscularity across Western countries. Psychology of Men \& Masculinity, 16(3), 337.

Gough, B., Hall, M., \& Seymour-Smith, S. (2014). Straight guys do wear make-up: Contemporary masculinities and investment in appearance. In S. Roberts (Ed.), Debating modern masculinities: Change, continuity, crisis? (pp. 106-124). London: Palgrave Pivot.

Gramsci, A. (1971). Selections from the Prison Notebooks (Q. Hoare \& G.N., Smith, Eds. \& Trans.) New York: International Publishers

Granato, S. L., Smith, P. N., \& Selwyn, C. N. (2015). Acquired capability and masculine gender norm adherence: Potential pathways to higher rates of male suicide. Psychology of Men \& Masculinity, 16(3), 246-253. https://doi.org/10.1037/a0038181

Halliday, M. A., \& Matthiessen, C. M. (1994). 32004. An Introduction to Functional Grammar. London: Arnold.

Halliday, M., \& Matthiessen, C. (2014). An introduction to functional grammar. Arbingdon: Routledge.

Harper, P. B. (1998). Are we not men?: Masculine anxiety and the problem of AfricanAmerican identity. Modern Fiction Studies, 44 (4), 993-995.

Hatfield, E. F. (2010). "What it means to be a man": Examining hegemonic masculinity in Two and a Half Men. Communication, Culture \& Critique, 3(4), 526-548. 
Holmqvist \& Gjörup, L. (2006). The Representation of Gender and Gender Roles in English Textbooks [Doctoral dissertation, Malmö University]

Horrocks, R. (1994). Masculinity in crisis. Self \& Society, 22(4), 25-29.

Hunter, S. C., Riggs, D. W., \& Augoustinos, M. (2017). Hegemonic masculinity versus a caring masculinity: Implications for understanding primary caregiving fathers. Social and Personality Psychology Compass, 11(3), e12307.

Judge, T. A., Livingston, B. A., \& Hurst, C. (2012). Do nice guys - and gals - really finish last? The joint effects of sex and agreeableness on income. Journal of personality and social psychology, 102(2), 390-407.

Kaufman, M. (1994). Men, feminism, and men's contradictory experiences of power. Theorizing masculinities, 142-165.

Kaya, A., Iwamoto, D. K., Brady, J., Clinton, L., \& Grivel, M. (2019). The role of masculine norms and gender role conflict on prospective well-being among men. Psychology of Men \& Masculinities, 20(1), 142- 147.

Kimmel, M. S. (2018). The contemporary "crisis" of masculinity in historical perspective. In Harry, B. (Ed.), The Making of Masculinities (pp. 121-153). London: Routledge.

Kluch, Y. (2015). 'The man your man should be like': Consumerism, patriarchy and the construction of twenty-first-century masculinities in 2010 and 2012 Old Spice campaigns. Interactions: Studies in Communication \& Culture, 6(3), 361-377.

Lavelle, K. L. (2020). The Face of Mental Health: Kevin Love and Hegemonic Masculinity in the NBA. Communication \& Sport, 2167479520922182

Lee, J. Y., \& Lee, S. J. (2018). Caring is masculine: Stay-at-home fathers and masculine identity. Psychology of Men \& Masculinity, 19(1), 47-58.

Lee, J. J., Lee, R. K. Y., \& Park, J. H. (2020). Unpacking K-pop in America: The Subversive Potential of Male K-pop Idols' Soft Masculinity. International Journal of Communication, 14, 5901-5919.

Leader, C. F. (2019). Dadvertising: Representations of fatherhood in Procter \& Gamble's Tide commercials. Communication Culture \& Critique, 12(1), 72-89.

Luyt, R., \& Foster, D. (2001). Hegemonic masculine conceptualisation in gang culture. South African Journal of Psychology, 31(3), 1-11.

Manchin, D., \& Mayr, A. (2012). How to do Critical Discourse Analysis. New York: Sage Publications

Marshall, D., Davis, T., Hogg, M. K., Schneider, T., \& Petersen, A. (2014). From overt provider to invisible presence: Discursive shifts in advertising portrayals of the father in Good Housekeeping, 1950-2010. Journal of Marketing Management, 30(15-16), 1654-1679.

McInroy, L. B., \& Craig, S. L. (2017). Perspectives of LGBTQ emerging adults on the depiction and impact of LGBTQ media representation. Journal of Youth Studies, 20(1), 32-46.

Mikorski, R., \& Szymanski, D. M. (2017). Masculine norms, peer group, pornography, Facebook, and men's sexual objectification of women. Psychology of Men \& Masculinity, 18(4), 257-267.

Möller, E. L., Majdandžić, M., \& Bögels, S. M. (2015). Parental anxiety, parenting behaviour, and infant anxiety: Differential associations for fathers and mothers. Journal of Child and Family Studies, 24(9), 2626-2637.

Orloff, J. (2017). The Empath's Survival Guide: Life Strategies for Sensitive People. Louisville: Sounds True.

Padgett, J. K. (2017). Mapping alternative masculinities: Development, validation, and latent profile analysis of a new masculinity measure. [Dissertation, University of Western Ontario]. Electronic thesis and dissertation repository. 
Peterson, D. (2016). Homophobic grammar: The role of transitivity and phoricity in homophobic formation. Journal of Language and Sexuality, 5(1), 61-93.

Ramaeker, J., \& Petrie, T. A. (2019). "Man up!” Exploring intersections of sport participation, masculinity, psychological distress, and help-seeking attitudes and intentions. Psychology of Men \& Masculinities, 20(4), 515.

Ricciardelli, R., Clow, K. A., \& White, P. (2010). Investigating hegemonic masculinity: Portrayals of masculinity in men's lifestyle magazines. Sex Roles, 63(1-2), 64-78.

Rosette, A. S., Mueller, J. S., \& Lebel, R. D. (2015). Are male leaders penalized for seeking help? The influence of gender and asking behaviours on competence perceptions. The Leadership Quarterly, 26(5), 749-762.

Schmitz, R. M. (2016). Constructing men as fathers: A content analysis of formulations of fatherhood in parenting magazines. The Journal of Men's studies, 24(1), 3-23.

Schwartz, J., \& Andsager, J. L. (2011). Four decades of images in gay male-targeted magazines. Journalism \& Mass Communication Quarterly, 88(1), 76-98.

Simpson, M. (1994). Here come the mirror men: Metrosexual men wear Paul Smith, use moisturizer, and know that vanity begins at home. The Independent. Retrieved December $12, \quad 2020$ from http://www.marksimpson.com/pages/journalism/mirror_men.html.

Snell, W. E. (1986). The masculine role inventory: Components and correlates. Sex Roles, 15(7-8), 443-455.

Sonnekus, T., \& Van Eeden, J. (2009). Visual representation, editorial power, and the dual 'othering' of black men in the South African gay press: The case of Gay Pages. Communication: South African Journal for Communication Theory and Research, 35(1), 81-100.

Stich, D.M. (2015, May 12). Guys are more vain than women. Metro. https://metro.co.uk/2015/05/12/guys-are-more-vain-than-women-we-knew-it5193026/

Thurman, N., \& Fletcher, R. (2020). Effects of a magazine's move to online-only: Post-print audience attention and readership retention revisited. Journalism Practice, 14(10), 1225-1243.

Way, N., Cressen, J., Bodian, S., Preston, J., Nelson, J., \& Hughes, D. (2014). "It might be nice to be a girl... Then you wouldn't have to be emotionless": Boys' resistance to norms of masculinity during adolescence. Psychology of Men \& Masculinity, 15(3), 241-252.

Williams, K. E., \& Koleva, H. (2018). Identification and treatment of peripartum anxiety disorders. Obstetrics and Gynaecology Clinics, 45(3), 469-481

Wodak, R. (2001). What CDA is about: A summary of its history, important concepts and its developments. In R. Wodak \& M. Meyer (Eds.), Methods of critical discourse analysis (pp. 1-13). London: Sage Publications.

Yang, H. C. (2014). Flower boys on campus: Performing and practicing masculinity. Journal of Gender Studies, 23(4), 391-408. 
APPENDIX

\begin{tabular}{|c|c|c|c|c|}
\hline $\begin{array}{l}\text { Semantic } \\
\text { category }\end{array}$ & Descriptions & Example clause/s & Source & Process category \\
\hline Male friendship & $\begin{array}{l}\text { A close but non sexual relationship } \\
\text { between heterosexual men. A unique } \\
\text { male bonding that involves a high level } \\
\text { of emotional intimacy. An exceptionally } \\
\text { tight and affectional exceeding that of } \\
\text { usual friendship }\end{array}$ & $\begin{array}{l}\text { l've known him for } 35 \text { years. [..]. I } \\
\text { think we fed on each other's } \\
\text { obsession during really formative, } \\
\text { important years that bonded us for } \\
\text { life }\end{array}$ & ART12 & $\begin{array}{l}\text { MENTAL, } \\
\text { BEHAVIOURAL }\end{array}$ \\
\hline $\begin{array}{l}\text { Emotional } \\
\text { expressiveness }\end{array}$ & $\begin{array}{l}\text { Ability to display an open expression of a } \\
\text { wide range of emotions including fear, } \\
\text { worry or sadness; feels comfortable } \\
\text { expressing emotions. }\end{array}$ & $\begin{array}{l}\text { He cries openly and easily. } \mathrm{He} \\
\text { effusively tells his male friends, "I } \\
\text { love you," often through those } \\
\text { tears. }\end{array}$ & REP9 & $\begin{array}{l}\text { BEHAVIOURAL, } \\
\text { VERBAL, } \\
\text { MENTAL }\end{array}$ \\
\hline $\begin{array}{l}\text { Intimacy/Sexual } \\
\text { activity }\end{array}$ & $\begin{array}{l}\text { Believes sex is a private, intimate and an } \\
\text { emotional experience instead of viewing } \\
\text { sex as a status symbol or a conquest to } \\
\text { assert dominance. }\end{array}$ & $\begin{array}{l}\text { I once kissed a woman who told me } \\
\text { the thing she like about kissing men } \\
\text { was that she could hang on their } \\
\text { shoulders }\end{array}$ & INT21 & BEHAVIOURAL \\
\hline Vulnerability & $\begin{array}{l}\text { Recognises personal weaknesses and } \\
\text { shortcomings and feels comfortable } \\
\text { interacting about his insecurities openly. }\end{array}$ & $\begin{array}{l}\text { I had antisocial behaviour and I was } \\
\text { hurting [...] I was feeling frightened, } \\
\text { or feeling judged, and it was a cry } \\
\text { for help }\end{array}$ & INT28 & $\begin{array}{l}\text { RELATIONAL, } \\
\text { MENTAL }\end{array}$ \\
\hline $\begin{array}{l}\text { Homosexual } \\
\text { judgment }\end{array}$ & $\begin{array}{l}\text { Being supportive of gay men and their } \\
\text { equality; comfortable in addressing his } \\
\text { own sexual orientation and interacting } \\
\text { casually about personal experience; } \\
\text { unconcerned about being perceived as } \\
\text { gay by other. }\end{array}$ & $\begin{array}{l}\text { I always wanted to surf, but I didn't } \\
\text { have the courage because I'm a bit } \\
\text { effeminate" }\end{array}$ & PRO2 & $\begin{array}{l}\text { MENTAL, } \\
\text { RELATIONAL }\end{array}$ \\
\hline \multirow[t]{3}{*}{$\begin{array}{l}\text { Spirituality and } \\
\text { religion }\end{array}$} & \multirow[t]{3}{*}{$\begin{array}{l}\text { Promotes a male spirituality that } \\
\text { emphasizes on a dualism between spirit } \\
\text { and body in which the spiritual } \\
\text { supremacy is identified as dominant } \\
\text { (masculine) and the body as requiring } \\
\text { control (feminine). }\end{array}$} & $\begin{array}{l}\text { I like to go to mass } \\
\text { He quit his job, boned up on } \\
\text { spirituality, philosophy and } \\
\text { psychology and then had a } \\
\text { hallelujah moment }\end{array}$ & INT15 & $\begin{array}{l}\text { BEHAVIOURAL, } \\
\text { RELATIONAL }\end{array}$ \\
\hline & & $\begin{array}{l}\text { Williams is part of the growing } \\
\text { modern breed, the meditation guru. }\end{array}$ & PRO42 & RELATIONAL \\
\hline & & $\begin{array}{l}\text { I believe in a more abstract God, } \\
\text { rather than one who must be praised } \\
\text { like an egomaniacal king }\end{array}$ & INT31 & MENTAL \\
\hline $\begin{array}{l}\text { Gender } \\
\text { Egalitarian and } \\
\text { Fluidity }\end{array}$ & $\begin{array}{l}\text { Has mutual respect for men and women } \\
\text { alike; approving of feminist outlook, non- } \\
\text { sexist and often work to achieve gender } \\
\text { equality. Constantly projecting positivity } \\
\text { towards changes in gender identity and } \\
\text { gender expressions. }\end{array}$ & $\begin{array}{l}\text { I do have my lines. Like, I can't wear } \\
\text { no skirt. Nor am I interested in } \\
\text { wearing a blouse. That's not my } \\
\text { deal. But things that are made for } \\
\text { women that I feel will look good on } \\
\text { me-that I like-I will wear," }\end{array}$ & PRO26 & $\begin{array}{l}\text { RELATIONAL, } \\
\text { MATERIAL, } \\
\text { MENTAL }\end{array}$ \\
\hline $\begin{array}{l}\text { Eco-friendliness/ } \\
\text { Green } \\
\text { consciousness }\end{array}$ & $\begin{array}{l}\text { Does not believe that eco-friendly } \\
\text { behaviours threaten their masculinity or } \\
\text { brand them as feminine. Genuinely } \\
\text { concerns about the environment and } \\
\text { does not feel emasculated by practicing } \\
\text { green behaviours, choices and attitudes. }\end{array}$ & $\begin{array}{l}\text {.if your totally straight bloke isn't } \\
\text { keen to shlep down to the shops } \\
\text { with a reusable bag, how about he } \\
\text { use his manbag }\end{array}$ & ART46 & MATERIAL \\
\hline
\end{tabular}




\begin{tabular}{|c|c|c|c|c|}
\hline $\begin{array}{l}\text { Health and } \\
\text { fitness }\end{array}$ & $\begin{array}{l}\text { Feels that the body is a critical element } \\
\text { in a man's identity. Views the body as a } \\
\text { site for self-improvement. Engages in } \\
\text { fitness activities to fulfil body culture } \\
\text { trends, on top of keeping healthy } \\
\text { lifestyle. }\end{array}$ & $\begin{array}{l}\text { I've participated in } 10 \mathrm{~km} \text { runs } \\
\text { before, but I was never satisfied } \\
\text { because of my times. }\end{array}$ & INT33 & $\begin{array}{l}\text { RELATIONAL, } \\
\text { BEHAVIOURAL }\end{array}$ \\
\hline $\begin{array}{l}\text { Fatherhood and } \\
\text { family }\end{array}$ & $\begin{array}{l}\text { Views fathers and husbands as an } \\
\text { important role model in a child's } \\
\text { development. Approach fatherhood } \\
\text { unconventionally. Rejects stereotypical } \\
\text { views of fathers as dominant and } \\
\text { authoritative disciplinarian. }\end{array}$ & $\begin{array}{l}\text { Being a family man and having a } \\
\text { wife and two children who I love } \\
\text { more than anything [... }\end{array}$ & PR017 & $\begin{array}{l}\text { RELATIONAL, } \\
\text { MENTAL }\end{array}$ \\
\hline $\begin{array}{l}\text { Aesthetic } \\
\text { consciousness }\end{array}$ & $\begin{array}{l}\text { Participates in male preening; practices } \\
\text { good grooming and beauty habits. } \\
\text { Addresses a paradoxical stance that } \\
\text { identify highly preened heterosexual } \\
\text { men as gay, yet does not distance } \\
\text { himself from physical or sexual } \\
\text { aesthetics. }\end{array}$ & $\begin{array}{l}\text { My routine entails moisturizing to } \\
\text { an almost obsessive degree. } \\
\text { I started using these six products } \\
\text { after stealing them from } \\
\text { girlfriends...... I smoothed a bit of } \\
\text { the rose-scented balm onto my lips, } \\
\text { and it was instantly clear that this } \\
\text { was the sort of lip-care experience I } \\
\text { had spent my whole life deprived of. }\end{array}$ & PR040 & $\begin{array}{l}\text { BEHAVIOURAL, } \\
\text { MATERIAL }\end{array}$ \\
\hline
\end{tabular}

\begin{abstract}
ABOUT THE AUTHORS
Nur Syuhada Radzi is a PhD candidate at Universiti Kebangsaan Malaysia. Her research interests include critical stylistics, studies of gender, masculinities and multimodal discourse analysis.

Kesumawati A. Bakar is a senior lecturer at the School of Language Studies and Linguistics, Universiti Kebangsaan Malaysia, Selangor, Malaysia. She holds a PhD degree (2012) in Linguistics from the University of Sydney, Australia. Her research interests include multimodal discourse analysis, corpus linguistics, gender and identity studies.

Bahiyah Abdul Hamid(PhD) is an Associate Professor at the Centre for Research in Language and Linguistics, Faculty of Social Sciences and Humanities, Universiti Kebangsaan Malaysia (UKM). Her research interests include language and gender, gender issues, identity construction, code alternation and code choice, and discourse and semiotics analysis. Bahiyah has headed an international research study funded by Qatar Foundation on linguistic sexism and gender role stereotyping and has headed numerous research projects nationally and at university level.
\end{abstract}

